Please cite this article as: Finsterwalder, J., Kupppelwieser, V.G. and de Villiers, M. (2012), The effects of film trailers on shaping consumer expectations in the entertainment industry - A qualitative analysis. Journal of Retailing and Consumer Services, http://dx.doi.org/10.1016/j.jretconser.2012.07.004

\title{
The Effects of Film Trailers on Shaping Consumer Expectations in the Entertainment
}

\section{Industry - A Qualitative Analysis}

Jörg Finsterwalder, Volker G. Kuppelwieser*, Matthew de Villiers

Jörg Finsterwalder

Senior Lecturer in Marketing

Department of Management

University of Canterbury

Te Whare Wānanga o Waitaha

Private Bag 4800

Christchurch 8140, New Zealand

Phone: +64 33642987 ext 8614

Fax: +64 33642020

Email: joerg.finsterwalder@canterbury.ac.nz

Volker G. Kuppelwieser

Adjunct Senior Lecturer

Chair of Service Marketing

University of Leipzig

Grimmaische Straße 12

04109 Leipzig, Germany

Phone: +49 1603601257

Email: volker.kuppelwieser@gmx.de

Matthew de Villiers

Sponsorship and Artist Liaison Manager

The Court Theatre

PO Box 268

Christchurch 8140, New Zealand

Phone: +64 39630870

Email: matt@courttheatre.org.nz

* Corresponding author 


\title{
The Effects of Film Trailers on Shaping Consumer Expectations in the Entertainment Industry - A Qualitative Analysis
}

\begin{abstract}
One can assume that there is most likely not a single person in the western world who has not been to a cinema, nor seen a trailer for a film to be released. This paper discusses consumer expectation influencers of film content and quality based on exploratory qualitative research using the screening of film trailers in New Zealand. The results show that the actors are the greatest influencers on film quality expectations; whilst genre has the greatest influence on film content expectations. This research underlines that whilst film marketers unlike film makers usually have no input in choosing actors, director or genre, they have the power to mediate how these are exposed to consumers in film trailers.
\end{abstract}

Keywords: film trailers, entertainment services, consumer expectations formation, film content, film quality, explorative research 


\section{Introduction}

One can assume that there is most likely not a single person in the western world who has not been to a cinema, nor seen a trailer for a film to be released. With the mass exposure of films to the public, the lack of research into the film industry may be surprising.

The motion picture industry is still experiencing major growth even though economic times are hard, with movie theatre admissions in the US increasing in 2008 by approximately 16\% from 2007 (Cieply and Barnes, 2009; Toumarkine, 2009). In New Zealand, box office revenues for 2008 reached approximately NZ\$ 157 million, a 3.2\% increase from 2007 (MPDA, 2009). This trend continued in 2009 (revenues of NZ\$ $169.9 \mathrm{~m} / 8.5 \%$ increase) followed by another record year in 2010 (revenues of NZ\$176.5 m / 3.8\% increase) (MPDA, 2010, 2011). This shows that a significant amount of a New Zealander's discretionary income is still spent on movie theatre entertainment, notwithstanding the financial crisis arising in 2008 (MPDA, 2009). The New Zealand film industry had to only face a 9\% drop (revenues of NZ\$ $161.8 \mathrm{~m}$ ) in 2011 due to external circumstances (earthquakes) but has had another promising start in 2012 (MPDA, 2012) comparable with other countries like the US (US Box Office is Up, 2012). According to the Motion Picture Association of America (MPAA, 2011), the worldwide box office reached a historic high of US\$ 32.6 billion in 2011; in fact, the motion picture industry will most likely not feel the effects of recessions much as it continues due to it being seen as a recession friendly industry (Recession Friendly Movies, 2009). This being said, however, only a small number of films released each year make money during their theatrical run (De Vany and Walls, 1999; Vogel, 1998), thus it is becoming increasingly important that a film is successful at attracting as large an audience as possible through the use of an effective promotional campaign. 
Consumers are exposed to films from a young age and by the time they are young adults they will have watched numerous film trailers, whether it be on television, the internet or at the cinema (Joshi and Hanssens, 2009). Studios usually spend around US\$ 10 million on the basic marketing (cutting, posters, market research, movie stars, premiers) and another US\$ 30 million on media buy (Friend, 2009) but according to Munoz (2005), it is not on television or newspapers that film advertisements will reach what she calls a "captured audience", but within movie theatres, full of people eager to watch a blockbuster. Trailers are so important to film marketers that they will spend significant amounts of money to have their trailer placed in the time slot just before the start of a summer blockbuster, when the movie theatre is full of keen moviegoers (Flanagan, 2012). If a film triumphs in its opening week, a good trailer will have played a significant role in its success (Gray, 2010) which can amount to over one third of the total box office sales in the first week alone (Acland, 2003).

Films are one of the most powerful media for storytelling and thus the key to effectively marketing them is through their emotional branding (McKee, 1997; Wolfe, 1999). Some trailers will be effective in arousing consumers' interest and encouraging them to want to see the film, whilst others may fail in consumers' minds and are simply forgotten about.

This research project aims to discover why some film trailers are more effective at encouraging consumers to want to see the film by determining consumers' immediate expectations after viewing a film trailer. The overarching aim of this research is to explore how consumers shape their expectations about films based on their exposure to film trailers, a topic that has not yet had any extensive academic research (d'Astous et al., 2007; De Vany and Walls, 1999; Elberse and Anand, 2007; Hixson, 2006; Joshi and Hanssens, 2009; Liu, 2006; Moul, 2007; Simonton, 2009; Stapleton and Hughes, 2005). 
Moul (2007) finds that the motion picture industry has been the subject of much research, but since the cessation of the publications "Current Research in Film: Audiences, Economics, and Law" in 1991, the number of topics in the area has decreased substantially. There has been academic investigation into consumers' expectations in service environments (Zeithaml et al., 1993), although this has never been applied to the motion picture industry.

This paper aims to fill the void in research by providing an overview of extant literature on consumer expectations, and applies it to the context of the motion picture industry. This research therefore explores the formation of consumer expectations from exposure to a film trailer. It attempts to highlight, from a consumer's point of view, which aspects of a film trailer capture their attention most effectively and are most influential on their expectations of a film.

\section{Literature Review}

\subsection{Film Trailers}

Entertainment industry comprises all services and activities in the fields of theatre, film, fine art, dance, opera, music, literary publishing, television and radio. Individuals or organisations involved in these fields engage in selling or otherwise profiting from creative works, activities or services provided by script writers, songwriters, musicians and other artists (Newsome, 2003; US Legal Definitions, 2012). Those involved in providing entertainment in the field of motion pictures have increasingly taken film trailers more seriously and have been using them as part of their film marketing strategy (Gray, 2010).

A film trailer is a brief film text providing a one- to three-minute cinematic experience that usually displays images from a specific feature film while emphasising its quality; it is created for the purpose of screening in theatres to promote a film's theatrical release (Kernan, 
2004). Trailers are a form of advertising and a unique form of narrative film exhibition, wherein promotional discourse as well as narrative pleasure are conjoined (Kernan, 2004). According to Belch and Belch (2007), film trailers are considered to be an affective form of advertising due to their visual and emotional nature, making them self-satisfaction, or affective, products or services. The clips usually contain portions of the advertised movie and are shown prior to other films the audience comes to watch (Hixson, 2006). The excerpts from the film represent and promote its overall tone and genre, story and star(s), and by "window shopping" (Kernan, 2004) this "free (film) sample" enables the moviegoer to decide whether the film is what they would want to watch (Hixson, 2006) because it condenses attractions and promises (McDonald, 2009). Most trailers comprise three distinct sections: The first section introduces the characters and environment in which the film takes place; the second section suggests some form of tension or change in the direction of the storyline; and the final section escalates the pace of the trailer and often alludes to a potential resolution.

Film trailers are the most effective promotional medium for the motion picture industry and are most influential on consumer expectations, thus it is extremely important for a film trailer to reach as wide an audience as possible (Hixson, 2006). This does not imply that consumers base their expectations solely on the film trailer. Previous research shows that people base their expectations of films on word of mouth (Liu, 2006; Moul, 2007), critic reviews and previous knowledge of parties involved in the production of the film, for example, actors or directors (Moul, 2007; Simonton, 2009), posters and viral marketing attempts (Elberse and Anand, 2007; Joshi and Hanssens, 2009), the country of origin of the film (d'Astous et al., 2007), box-office performance and award nominations and wins (Simonton, 2009). 
Much of the extant literature on the motion picture industry relates to the idea that film marketers should create interactive online universes (Stapleton and Hughes, 2005) or target their film promotional campaigns to specific consumer segments in order to be successful (Hixson, 2006); whilst other film researchers focus on the content and overall tone of the trailers as a way of targeting audiences (Bridges, 1993) as well as the amount and appropriateness of music in the trailer; yet none of them investigates whether it is possible to produce an enhanced promotional campaign that is suitable for a wide range of consumers. Not only would this be more economically beneficial for the motion picture industry in terms of production costs involved with producing trailers, but also in placing these trailers in different filmic locations for these different consumer segments.

Bridges (1993) concentrates on the effects of film trailers on consumer expectations, with a focus on the content and overall style of the trailers. The author establishes that consumers form expectations about films based on their usage situation, for example, going to the movies with one's partner versus taking one's family out for a family evening. Film trailers should therefore accurately portray the genre of the film (Bridges, 1993). Individuals form expectations of a film based on the orientation of the advertising and thus are more likely to be satisfied by the film if it meets these expectations. If a film is promoted as an experience for the entire family, people will most likely assume it will be family friendly and will have a wholesome theme. If the film then is perceived as a period drama, then the family-oriented expectation will not have been met.

Eastman et al. (1985) support this argument and show that exposure to a film trailer produces increased expectations of the amount of particular content in a film. A film advertised primarily as a comedy will therefore attract consumers who are interested in watching a comedic film, whilst conversely will leave consumers disappointed if it does not meet its promise. The 
researchers highlight the notion of the accurate portrayal of content and genre (tone) in film trailers in order to create realistic expectations.

The overall tone of a film trailer can also be directly influenced by the use of music in the trailer. Flanagan (2012) notes that since the beginning of the MTV generation in the 1980s, trailers have relied heavily upon music as a way of highlighting particular aspects of the trailer, as well as increasing the overall pace of the trailer by connecting multiple scenes. Music can also be used to portray a particular theme of a film as consumers often relate specific types of music with particular feelings, for example, soft music with romance. The audio component of an advertisement can also have a major effect on a consumer's response to the communicated message.

Leigh (1991) explains that if the audio and video components of the message are congruent with one another, i.e. highly related, consumers will more likely encode the message as a unified whole. This notion is expanded on by Gorn (1982), when he establishes that a consumer's liking of the music used in an advert can directly affect their product preferences. If consumers dislike the audio component of an advertisement, they are likely to transfer these negative feelings to the product or service being advertised. Film marketers therefore use a certain style and tempo of music to portray the film to be a particular genre or have a specific tone, which in essence effects consumers' expectations of such content in the film.

\subsection{Consumer Expectations}

According to Zeithaml et al. (1993) consumer expectations are beliefs about a product or service that serve as standards or reference points against which performance is judged. A consumer will form expectations of a product or service from exposure to promotional material, 
word of mouth, any other forms of advertisement and prior experience and knowledge; whilst secondly they use these expectations as reference points to judge the performance of the product or service when they consume it (Bridges, 1993).

One of the main factors influencing expectations is the consumers' prior knowledge and experience with the product or service on offer (Carman, 1990). Many consumers have prior knowledge of the film industry when watching trailers, such as of actors, directors, film studios and writers; however this is not necessarily the case for all consumers. Herr (1989) finds that less well informed consumers are more likely to base their expectations of a product or service solely on their perceptual judgments of a promotional campaign; whilst knowledgable consumers will use assimilation effects to compare and contrast with previous experience.

This prior knowledge effect can be counteracted in the film industry by providing consumers with as much information about a film as possible, whilst still attempting to keep an air of mystery with the film (Moul, 2007). The question to be asked is what the correct amount of information provided to consumers is? Film trailers are film advertisers' primary medium for advertisement, and subsequently the most commonly used method for consumers to learn about a film (Hixson, 2006), thus it is within these trailers that it is of great importance to provide adequate information about a film. If a film studio provides too much information about a film they risk to expose the plot or storyline of the film; and conversely if they provide too little information they may leave consumers uninterested in the film. Certainly, a consumer can acquire information about a film through the film's website or websites which contain evaluations of films or movie databases, but they will most likely not engage in active information seeking if the film trailer does not inspire them to do so. 


\section{Method}

The aspect of a film's promotional campaign under investigation is the film's trailer; thus the film's posters, website and any other (viral) marketing approaches are not included in this study. The reason for this approach is that the film trailer has been found to be the most effective advertising medium used by film advertisers to communicate to consumers (Hixson, 2006). To narrow the field of potential trailers to use for the purpose of this study, from a total of twenty-six genres (IMDB, 2009) we selected four different film genres (comedy, thriller, romance and horror), which were to be released internationally after September 2009 to ensure that none of the participants in our exploratory study had viewed any of the films whilst the research was being carried out. In addition, it was important that there were two films of each genre selected for investigation to allow for comparison of film trailers within each genre in order to solidify any results found regarding cross-genre comparisons (IMDB, 2009). Three months were allowed as a sampling period for the second film as most films released after December 2009 did not have trailers (IMDB, 2009).

Four trailers with one from each genre were screened to twelve commerce students, six male and six female participants, with an average age of 22.25 years, consecutively. This process was repeated several days later for the remaining four trailers. The trailers were screened to all twelve participants simultaneously in a small university lecture theatre in order to reproduce the sound, video quality and atmosphere of a movie theatre as closely as possible. This allowed the participants to experience viewing the film trailers on a large screen with appropriate sound levels as if they were viewing them in an actual movie theatre. 
Semi-structured interviews were selected as the most appropriate qualitative research method as they reduce any cross-contamination effects that may have been found using other research methods, such as focus groups, and for yielding rich data (Esterberg, 2002). No specific interview questions were formed; instead, seven topics were addressed: 1) general discussion about film trailer viewing experience; 2) general expectation formation; 3) storyline exposure and intrigue; 4) style of trailer; 5) genre preferences; 6) effects and appropriateness of music; and 7) the effect of actors, directors and writers in film trailers. All results of the interviews were transcribed and pseudonyms used to replace students' real names.

\section{Findings}

\subsection{Factors affecting consumer expectations of film quality}

Carman (1990) and Celsi and Olson (1988) establish that one of the main influences on the formation of consumer expectations is prior knowledge or involvement with a product or service. In the film industry, actors, directors and writers provide consumers with this prior knowledge. The results of the participative study show that people involved in a film have a direct influence on how consumers form expectations of the quality of the film; however, these individuals do not influence how consumers form expectations of the content of the film. Herr (1989) states that consumers with different levels of knowledge base their expectations of products and services on perceptual judgements versus previous experience. The interview results show that the participants have high levels of knowledge of actors, thus previous experience is important; however, they have low levels of knowledge of directors and writers, thus perceptual judgements of the trailers is of key concern. 
Of all the stakeholders involved in the production of a film, the actors are the face to the public. This is particularly evident throughout the interviews when the interview participants constantly refer to the films' actors by name. As highlighted by Simonton (2009), actors are very influential for one major reason; they have a proven track record that allows consumers to form pre-determined expectations of their acting ability as their "previous bodies of work are a good indication of what you can expect from them in a movie" (Stu). This influence has positive and negative repercussions; some participants indicate that they will have higher expectations of a film due to the actors' previous body of work; because, as Tess puts it, "Really good actors won't waste their time with an average or bad film"; whilst others participants point out that if particular actors are in a film then they will avoid it regardless of its storyline.

The other effect that an actor's track record has on consumer expectations is the congruency between the genre of their previous work and their new film. The realistic emotional portrayal of storyline is seen to be an important factor among the participants and they feel that actors who had not previously been in films of a particular genre and are then "appearing in a film that was opposite to their norm could create a weird feeling” (Rachel).

The writer of a film was found to have no effect on the participants' expectations. During the interviews it was apparent that none of the participants felt that their expectations were influenced by the writer of a film.

Most of the participants are of the view that they know enough about directors to make educated judgments about the quality of their films and thus directors do not affect their expectations. However, there are certain well known directors and the participants have higher expectations for films connected to these names. It is visible that "the majority of the time, they [the directors] don't influence me, it's only with certain directors that there is any influence at 
all" (Rachel). Whilst this finding is somewhat incongruent with other research which establishes that directors have an important effect on consumers' expectations, it highlights the need for film marketers to overcome this potential limitation in their film trailers (Moul, 2007; Simonton, 2009).

Consumers often have higher expectations of a product or service compared to what it can actually offer (Zeithaml et al., 1993) and an organisation therefore needs to honour any promises it makes (McMath, 1998). This is also visible from the interviews, when, for example, Randy stresses that he would, "expect the film to live up to the expectations a trailer creates; therefore a trailer needs to manage the expectations it creates so that I'm not disappointed". For film marketers, the most appropriate way to manage consumer expectations is through the style of the trailer as it should encapsulate the overall style of the film (Bridges, 1993). As Rachel adds, "If the style of the trailer wasn't the same as the film it would seem like false advertising".

The results show that the style of a trailer is used by the participants as a direct indicator of the expected quality of a film. Flanagan (2012) maintains that the style of a trailer consists of multiple storytelling elements which should all be connected synergistically. All participants agree that a trailer needs to reflect the overall style of the film whilst capturing one's attention, setting the speed of the film and drawing the viewer into the storyline.

Mary summarises the reason for an effective stylistic approach to a trailer when she says, "If a trailer has all of the right stylistic elements it looks like a lot of effort has gone into making it, and if you put a lot of effort into making the trailer then the film must have a lot of effort too." This perception is congruent with the other participants' views. 


\subsection{Factors affecting consumer expectations of film content}

With regard to the music used in trailers and its influence on expectations, "a poor choice in music can greatly affect how one views something, even creating a false impression of what a film can be like. $[\mathrm{O}] \mathrm{r}$ it clashes so much with the visual that it leaves a horrible impression" (Rachel). The participants' responses show that music plays a significant role in the formation of expectations relating to the content of a film. Flanagan (2012) states that the music played within a film trailer has a dual role of hiding flaws and providing information about a film. This is supported when all but one of the participants indicate that music plays a pivotal role in creating the overall mood and tone of the trailer, thus drawing the viewer into the storyline of the trailer without being consciously aware of it.

The film trailer literature indicates that genre is an important influencer of expectations for two reasons. Firstly, the accurate portrayal of genre ensures that consumers create realistic expectations of the film (Bridges, 1993); and secondly, genre preferences are of great importance because people will more likely pay attention to something that is personally relevant to them because they will see the entertainment value in it (Celsi and Olson, 1988; Hixson, 2006).

Every participant states that there are particular genres that they would not willingly choose to watch; thus the accurate portrayal of genre in trailers seems of great concern to them. When asked if the genre should be easily identifiable, Laura states that, "it shouldn't be too obvious, but people should have little doubt of the genre, in case it is a type of movie that they hate", and Randy further elaborates, "if it's a genre I don't like I won't even bother watching the trailer". 


\subsection{Factors affecting consumer expectations of film quality and content}

Consumers have the ability to comprehend a substantial amount of information within a trailer in a matter of seconds and capture the gist of the trailer (Maljkovic and Martini, 2005; Olivia, 2005). Consumers make their own assumptions about the storyline of the film based on the 60 to 180 seconds of content of the trailer. The story aspect of a trailer is found to have a dual effect on consumer expectations as it not only outlines the potential content of the film, but also the potential quality of the film. It can be summarised that the story aspect comprises three separate elements; 1) plot, 2) dialogue, and 3) storyline exposure. The findings show that the storyline exposure only has an effect on consumer expectations of film content; whilst the plot and dialogue have a dual effect on expectations of film quality and film content.

McKee (1997) and Wolfe (1999) state that the key to effectively marketing a storytelling medium such as film is through emotional branding. The participants' responses show that the most emotionally influential aspect of a trailer is the plot of the film itself and "when you watch a movie, something has to inspire you, so a trailer should do the same thing” (Tess). The plot of a trailer is seen to be equally influential on both the expectations of the quality of the film and the content of the film. Flanagan (2012) shows the importance of an effective plot development within a trailer. However, the participants' views indicate that some of the trailers screened lack any discernable storyline with one participant commenting, "even if I like those genres, they lacked direction" (Patricia). A trailer should not be perceived "like a bunch of random clips from the movie have been shoved together" (Tim). It should rather "have a storyline like the film" (Jack), thus reflecting the content of the film. All participants agree that the plot of the film is crucial to their decision to want to watch it. If the trailer does not show the film to have a proper 
plot, regardless of their genre preferences, they would have low expectations of the film and subsequently would have no desire to watch it.

A recurring theme throughout the interviews is the importance of the dialogue shown in the trailer as an influencer of the participants' expectations of both the quality of the film and the film's dialogue content. Randy states that, "dialogue should be good in the trailer to show the movie has good dialogue" thus connecting the quality of the dialogue in the trailer with the quality of the dialogue to be expected in the film. Kat on the other hand believes that "dialogue is indicative of the storyline" and the best way for film marketers to convey what the film is about. Overall, the participants agree that irrespective of genre, the quality of the dialogue revealed in the trailer is indicative of the quality of the dialogue in the film and thus influences their expectations of the film. Comparatively, the actual dialogue used in the trailer is indicative of the film's story and thus influences their expectations.

It is reflected in the interview results that the exposure of storyline in a trailer is an important influencer of a consumer's expectations of the film content for two reasons; firstly, there needs to be a proportionate amount of content exposed within the trailer itself; and secondly, the overexposure of storyline can result in a lack of intrigue.

Eastman et al. (1985) state that exposure to a film trailer produces increased expectations of the amount of certain content in a film. The interview results support this. For example, Kat says, "I don't like overexposure, for example, when they show all the funny bits or action sequences, because you expect too much! There needs to be a proportionate exposure of different elements to the film". A trailer should therefore strive to create a realistic expectation of the various elements of content in a film. 
As one of the main aims of film trailers is to create intrigue about the film, it is important that film marketers include an appropriate proportion of storyline in the trailer (Moul, 2007). The participants indicate that there is a fine line between film trailers creating intrigue versus revealing too much of the film so that "there should be enough for me to tell it's going to be a good movie but if you get too much storyline what's the point in watching it?" (Mary). The overarching feeling among the participants is that a trailer should have a teaser effect in regard to the film's offer, but should limit information on the storyline. The participants believe that if consumers desire to increase their knowledge on the film's storyline, they should engage in seeking further information. Nevertheless, a trailer should be enticing enough to garner one's interest without revealing the film's entire content.

Figure 1 summarises the findings by showing a suggested model with the influencers of film expectations as explored in this qualitative study of film viewers' exposure to movie trailers.

--- Figure 1 about here ---

\section{Discussion and Limitations}

Now that it has been established how expectations are formed in regard to feature films and which influencers have an effect on consumer expectations of film content and quality, it is important to discuss how film marketers can use this knowledge to their advantage through manipulating these variables. From the conceptual model it can be derived that film marketers have a high degree, or direct control over certain elements within a trailer such as the style of the trailer, the story (the plot of the film, the dialogue shown, the amount of storyline exposure) and 
the music used; whilst they have a lower degree, or only indirect control over other elements such as the film's genre and the people involved in making the film (actors, director).

The results indicate that genre is one of the most important expectation influencers. Genre preference strongly dictates 'liking' of a film trailer. Although only indirectly controllable, it is important that film marketers select the most appropriate scenes from the film which reflect the genre most realistically. Consumers have very strong opinions about their genre preference and most of them agree that there are certain genres they would not be interested in.

The other influencer highlighted in the study is the choice of individuals involved in making the film, i.e. the actors and director. The results show that whilst well known directors have a strong positive influence on expectations of the quality of a film, the effect is limited to a few. For this reason, in the trailer film marketers should create a connection of new films to successfully released films shot by the same director. Not only does this highlight other films the director has previously directed, but by naming a film which has the same genre and feel to it, or better yet a commercial success, provides consumers with additional knowledge about the director.

A film marketer has no control over the casting of the actors as it is the studio's and casting director's choice; therefore the marketer's task is to select episodes from the film which best portray the actors' performance. As not all actors are equally liked by the audience, film marketers should focus on the film itself and show the actors chosen are well suited to their role.

Some expectation influencers are within the film marketer's control. Film marketers can influence the music used in a trailer. The results indicate that consumers enjoying the music in a trailer may find the potential film increasingly interesting and this influences their expectations. The results show that music engenders a strong emotional response when it corresponds with the 
visual elements of the trailer. Using music from the film's soundtrack is therefore not essential; however, the emotional response that is engendered during the exposure to the trailer would most likely be repeated when the same music is played during the film. Furthermore, often prominent musicians are chosen to compose and/or perform film music. Making use of this additional marketing opportunity by incorporating elements of the music from a prominent composer / singer into the trailer may influence expecations and entice more consumers to go and watch the film.

In order to most effectively influence consumers' expectations of the overall style and quality of the film, the style of the trailer should be consistent with the style of the film. In a trailer there is very little time to establish a particular style compared to a film; however, film marketers can reflect this style through using proportionate amounts of content from the film in the trailer.

The results also show that consumers require trailers to provide them with enough information about a film's story to make a judgment about the potential quality of the film's overall storyline. Consumers desire a reasonable amount of information about the plot of a film in a trailer so that if asked they can explain it to others. Film marketers should therefore aim to create a trailer that can act as a self-contained unit, giving consumers enough information to intrigue them without exposing too much content.

The exposure of dialogue and storyline is therefore of great importance to film marketers because of all the elements these are the ones they have the greatest control over. The selection of dialogue should be of key concern to film marketers as this seems to be indicative of a good film. However, consumers are used to being exposed to the best lines of dialogue in trailers. Therefore, film marketers cannot simply rely on enticing dialogues in a trailer to sell a film. 
The exposure of storyline has to be dealt with great care to intrigue consumers without revealing too many minor details and specifically not the ending of the film. Consumers may expect the amount of content in a film's trailer to be comparative with the amount of content in the film and consequently shape their expectations accordingly.

The literature review highlights the limited amount of extant research into the motion picture industry, and more particularly, how film trailers effectively influence consumers' expectations of films. This research project aims to further advance the existing knowledge of how consumers form expectations through advertising exposure by using film trailers as a basis.

Film trailers and standard advertisements have several similarities: i) they both contain similar messages that highlight the offer's features; ii) they usually comprise slogans and brands; and iii) they use the producer's or manufacturer's reputation as a lever to increase attractiveness of the offer. One difference between film trailers and standard advertising is that film trailers try to sell stories and the consumer can already directly pre-test elements of the service (see also Kernan, 2004) by encountering a direct consumer experience watching the trailer (direct vehicle for a consumer experience), whilst most standard advertising aims at selling products or services by trying to entice the consumer to buy a prospective consumer experience without offering a direct pre-test (indirect vehicle for a consumer experience). It is this characteristic that differentiates film trailers from other forms of advertising and it is therefore important to research how this added element effects consumer expectations. Whilst one may attempt to generalise the results of this research to the wider advertising industry with regards to the quality influencing aspect, the content influencing aspect is entertainment industry specific.

This research explores how and which of the elements of a film trailer influence consumers' expectations of films. From the in-depth interviews with the research participants, a 
set of film trailer influencers was deduced which can be used for future quantitative research. Future research may also incorporate novel ideas for pre-screening activities to increase audience involvement and drive more participation when watching trailers and how this may influence consumer expectations. Through handsets moviegoers will be able to engage with what is on the screen. It is also envisioned that information about trailers but also film reviews and branded entertainment will be shared in the movie theatre (Fuchs, 2012).

Some limitations have to be kept in mind when interpreting the results. The research in question is of a qualitative nature using a small sample size of twelve students and therefore may not be generalisable to a larger audience. No more than four of the twenty-six existing genres, as defined by IMDB (2009), were studied and thus the results may not be generalisable for all genres. Only a certain demographic was studied which may not be representative of a general movie theatre audience. The only aspect of a film's promotional campaign under investigation was the film trailer, which ignores any other film promotional activities that may influence consumer expectations. Addionally, the order in which the trailers were screened to participants may have affected their responses. Although otherwise instructed, but if any of the participants discussed their feelings about the films in the time between the trailer screening and their interviews this could have potenially influenced their expectations. 


\section{References}

Acland, C. R., 2003. Screen traffic: movies, multiplexes, and global culture. Durham: Duke University Press.

Belch, G. E., Belch, M. A., 2007. Advertising and Promotion: An Integrated Marketing Communications Perspectives. New York, NY: McGraw-Hill/Irwin.

Bridges, E., 1993. Service attributes: Expectations and judgments. Psychology \& Marketing 10 (3), 185-197.

Carman, J., 1990. Consumer perceptions of service quality: An assessment of the SERVQUAL dimensions. Journal of Retailing 66 (1), 33-55.

Celsi, R. L., Olson, J. C., 1988. The Role of Involvement in Attention and Comprehension Processes. Journal of Consumer Research 15 (2), 210-224.

Cieply, M., Barnes, B., 2009. Americans Flock to the Movies, Seeking a Silver-Screen Lining. New York Times, 01 Mar 2009, A1.

d'Astous, A., Colbert, F., Nobert, V., 2007. Effect of Country-Genre Congruence on the Evaluation of Movies: The Moderating Role of Critical Reviews and Moviegoer' Prior Knowledge. International Journal of Arts Management 10 (1), 45-51.

De Vany, A., Walls, W. D., 1999. Uncertainty in the movie industry: Does star power reduce the terror of the box office? Journal of Cultural Economics 23 (4), 235-318.

Eastman, S. T., Bradbury, D. E., Nemes, R. S., 1985. Influences of previews on movie viewers' expectations. In: Austin, B. A. (Ed.), Current research in film: Audiences, economics, and law, Norwood, NJ: Ablex Publishing, pp. 51-57. 
Elberse, A., Anand, B., 2007. The effectiveness of pre-release advertising for motion pictures: An empirical investigation using a simulated market. Information Economics and Policy 19 (3/4), 319-343.

Esterberg, K. G., 2002. Qualitative Methods in Social Research. New York: McGraw-Hill.

Flanagan, M., 2012. How to Edit a Trailer That Will Get Yours Film Noticed. http://www.microfilmmaker.com/tipstrick/Issue14/Edit Trl.html (accessed 17 April 2012).

Friend, T., 2009. The Cobra. The New Yorker, 19 January 2009, 41.

Fuchs, A., 2012. Engaging the audience: cinema keeps moviegoers in sync with advertising. Film Journal International $115(4), 34$.

Gorn, G. J., 1982. The Effects of Music in Advertising On Choice: A Classical Conditioning Approach. Journal of Marketing 46 (1), 94-101.

Gray, J., 2010. Show Sold Separately. New York: New York University Press.

Herr, P., 1989. Priming Price: Prior Knowledge and Context Effects. Journal of Consumer Research 16 (6), 67-75.

Hixson, T. K., 2006. Mission possible: Targeting trailers to movie audiences. Journal of Targeting, Measurement and Analysis for Marketing 14 (3), 210-224.

IMDB, 2009. Internet Movie Database. http://www.imdb.com (accessed 01 September 2009).

Joshi, A. M., Hanssens, D. M., 2009. Movie Advertising and the Stock Market Valuation of Studios: A Case of “Great Expectations?”. Marketing Science 28 (2), 239-250.

Kernan, L., 2004. Coming Attractions: Reading American Movie Trailers. Austin: University of Texas Press. 
Leigh, J. H., 1991. Information Processing Differences Among Broadcast Media: Review and Suggestions for Research. Journal of Advertising 20 (2), 71-75.

Liu, Y., 2006. Word of Mouth for Movies: Its Dynamics and Impact on Box Office Revenue. Journal of Marketing 70 (3), 74-89.

Maljkovic, V., Martini, P., 2005. Short-term memory for scenes with affective content. Journal of Vision 5 (3), 215-229.

McDonald, P., 2009. Miramax, Life is Beautiful, and the Indiewoodization of the foreignlanguage film market in the USA. New Review of Film and Television Studies 7 (4), 353375.

McKee, R., 1997. Story, Substance, Structure, Style, and the Principles of Screenwriting. New York, NY: Harper.

McMath, R., 1998. Don't make empty promises. American Demographics 20 (2), 64.

Moul, C., 2007. Measuring Word of Mouth's Impact on Theatrical Movie Admissions. Journal of Economics \& Management Strategy 16 (4), 859-892.

MPAA, 2011. Theatrical Market Statistics. http://www.mpaa.org/policy/industry (accessed 17 April 2012).

MPDA, 2009. MPDA Press Release 2008. http:/www.mpda.org.nz/press-releases (accessed 17 April 2012).

MPDA, 2010. NZ Movie-Goers Make 2009 a Record Year at the Box Office. http://www.mpda.org.nz/press-releases (accessed 17 April 2012).

MPDA, 2011.2010 A Record Year at the Box Office. http://www.mpda.org.nz/press-releases (accessed 17 April 2012). 
MPDA, 2012. 2011 a Challenging Year for NZ Film Industry. http://www.mpda.org.nz/pressreleases (accessed 17 April 2012).

Munoz, L., 2005. Trailers: How a small time slot adds up to a big industry headache. http://seattletimes.nwsource.com/html/movies/2002181046 trailers16.html (accessed 17 April 2012).

Newsome, K., 2003. Designing Manager Contracts for Musicians. Entertainment and Sports Lawyer $21(2), 1-15$.

Olivia, A., 2005. Gist of a Scene. In: Rees, I. L. G. \& Tsotsos, J. K. (Eds.), Neurobiology of Attention, San Diego, CA: Elsevier, pp. 251-256.

Recession Friendly Movies, 2009. Recession Friendly Movies. Film Journal International 112 (3), 3 .

Simonton, D. K., 2009. Cinematic Success Criteria and Their Predictors: The Art and Business of the Film Industry. Psychology and Marketing 26 (5), 400-420.

Stapleton, C. B., Hughes, C. E., 2005. Mixed Reality and Experiential Movie Trailers: Combining Emotions and Immersion to Innovate Entertainment Marketing. IEEE Computer Graphics and Applications 25 (6), 24-30.

Toumarkine, D., 2009. Cinemas the recession: Survive or thrive? a crash course. Film Journal International 112 (3), 20-23.

US Box Office is Up, 2012. 2012 Box Office is Up by 22\%. Film Journal International 15 (4), 6. US Legal Definitions, 2012. Entertainment Industry Law \& Legal Definition. http://definitions.uslegal.com/e/entertainment-industry/ (accessed 19 April 2012). Vogel, H. L., 1998. Entertainment Industry Economics. Cambridge, MA: Cambridge University Press. 
Wolfe, M., 1999. The Entertainment Economy: How Mega-Media Forces are Transforming Our Lives. New York, NY: Three Rivers Press.

Zeithaml, V., Berry, L., Parasuraman, A., 1993. The nature and determinants of customer expectations of service. Journal of the Academy of Marketing Science 21 (1), 1-12. 
Figure 1: Suggested model with film expectations influencers

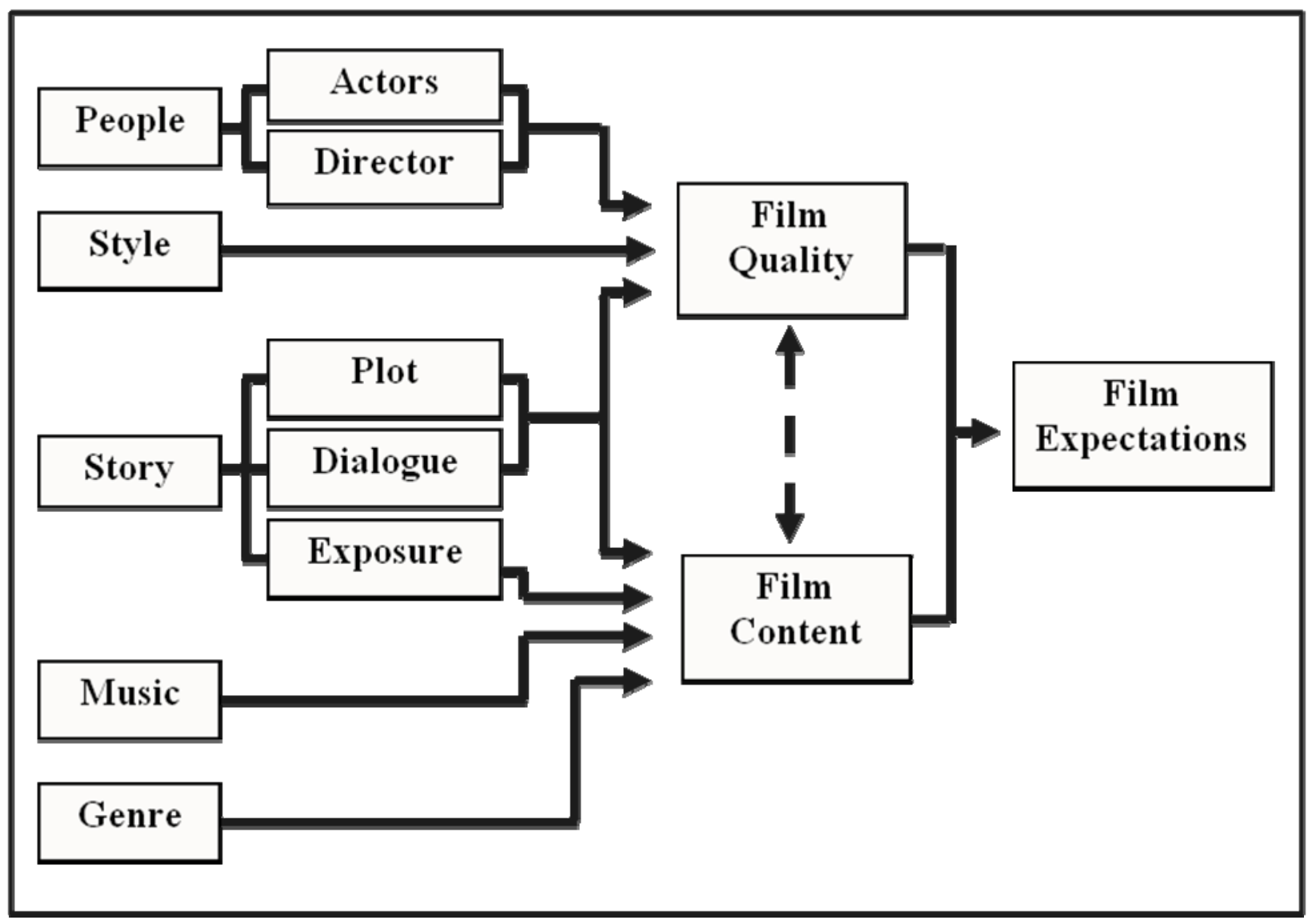

